УДК $225.03=163$ '37

https://doi.org/10.18485/msc50_vuk_trsic.2021.ch24

Ангелина Минчева

\title{
ЦРКВЕНОСЛОВЕНСКА ЛЕКСИКА У ПРЕВОДИМА НОВОГ ЗАВЕТА ВУКА КАРАЏИЋА И НЕОФИТА РИЛСКОГ
}

У анонимној рецензији Франца Миклошича поводом Вуковог превода Новог завета помињу се оба бугарска превода која су дотада изашла: Сапуновљев (1828, Букурешт) и Неофита Рилског (1840, Смирна). По Миклошичу ниједан од њих није успешан, јер им је језик мешавина црквенословенског, бугарског и руског. ${ }^{1}$

Сапуновљев превод заиста није од значаја за историју бугарске препороне књижевности, али је превод Неофита Рилског доживео 6 издања ${ }^{2}$. Мада је дело једног изузетно образованог књижевника, аутора прве бугарске граматике (1835), представника тзв. славенобугарске школе у концепцијама изградње националног бугарског књижевног језика, Нови завет Н. Рилског остао је ван пажње истраживача како приликом проучавања књижевне норме у доба препорода, тако и у радовима, специјално посвећеним књижевној делатности Неофита Рилског. Не улазећи у детаље добијених резултата, напоменућемо само да је $\mathrm{H}$. Рилски први препородни књижевник с јасно формулисаном реалистичком концепцијом о начину изградње националног књижевног језика и његовог облика. То би морао бити књижевни језик који би, не одвајајући се од народног језика, ујединио дијалекатску разноликост и истовремено укључио у своја изражајна средства богатство црквенословенске писмене традиције - једна концепција чије је практично остварење било веома тешко, са више могућности за кодификацију у области граматике него

1 Упор. о томе Вл. Мошин, Вуков „Нови завјет”, Сабрана дела Вука Караџића, $\mathrm{X}$, Нови завјет, Приредили Владимир Мошин, Димитрије Богдановић, Београд, 1974, с. 576 и нап. 157, с. 577.

21 - Смирна, 1840; II - Смирна, 1850; III - Букурешт, 1853 и Лондон, 1859; IV - Букурешт, 1857, V - Букурешт, 1859; VI - Букурешт, 1859. Упор. Ив. Д. Шишманов, Нови студии из областти на българското Възраждане, I, София, 1926, c. 441-443. 
при успостављању лексичког фонда бугарског књижевног језика ${ }^{3}$. Обично се о Н. Рилском као филологу суди по његовој Бугарској граматици и не узима се у обзир чињеница да управо у преводу Новог завета можемо тражити практично остварење Неофитових схватања о бугарском књижевном језику и путевима његовог развоја. Познато је да је Вуков превод настао не само зато да би постојао српски превод Новог завета, него и као текст-образац како мора изгледати српски књижевни језик. Н. Рилски такође улаже у своје дело нешто више од жеље да осигура разумљив текст Новог завета за бугарске хришћане који су били лишени самосталне црквене организације и званично су припадали грчкој православној цркви. У складу с његовом Бугарском граматиком то је превод са „славенскагш на бо́лгарскій жзыкъ”. Из овога проистиче да би једно поређење превода Новог завета В. Караџића и Н. Рилског било оправдано не само због њиховог пионирског карактера и релативно кратког временског периода који их раздваја ${ }^{5}$. Много је битније што су се у својој књижевној делатности руководили одређеним принципима и убеђењем

${ }^{3}$ Упор. Неофит Рилски, Болгарска граматика, Фототипно издание, София, 1984 (Болгарска грамматика, Сега перво сочинена, Въ Крагуевць, 1835), с. 1-73. Предговор (Хр. Пьрвев); Л. Андрејчин, Из историята на нашето езиково строителство, София, 1977; Хр. Пьрвев, Очерк ко история на болгарската граматика, София 1975; Вл. Мурдаров, Диалектната основа на езика на Н. Рилски, отразена в „Болгарска граматика” (1835), Български език, 1-2, 1972, с. 14-21; П. Ненкова, Към спецификата на черковнославянското влияние у Неофит Рилски (с оглед кбм лексиката), Изследвания из историята на българския книжовен език от миналия век, София, 1979, с. 117-122; Ст. Стоянов, Началото на науката за новобългарския език (Кбм 150-годишнината на „Болгарска грамматика” от Неофит Рилски), „Език и литература”, 4, 1985, с. 9-18; В. Кювлиева, Българско-грбцкият словар на Неофит Рилски - важно свидетелство за развойните тенденции в лексиката на новобългарския език през втората и третата четвърт на миналия век, Език и литература, 2, 1986, с. 31-37; Хр. Пьрвев, Проблеми на българската ккнижовноезикова лексика през третата четвърт на ХIX век, „Език и литература”, 1, 1986, с. 1-12.

${ }^{4}$ Овде користимо II издање Неофитовог превода. У свом писму (Неофитъ словеснейшему учителю Габровскому Г., 1941) Неофит Рилски каже да је веома задовољан што је „нащампанъ новый завътъ на нашъ природный язык”. На исти начин га квалификује и Кипиловски: „на природномъ нашемъ языкъ”. Упор. Ив. Д. Шишманов, нав. дело, с. 442.

${ }^{5}$ О историји тих превода види в. Мошин, нав. дело, с. 511-569. и Ив. Д. Шишманов, нав. дело, с. 66-67, 78, 147 и Р. Радков, Неофит Рилски и новобългарската култура, София, 1983, с. 95-104. Интересантна је чињеница да су Неофита оптужили за „лутірокалиинство” (писмо Н. Христовића од 14. VI 1840) - Ив. Д. Шишманов, нав. дело, с. 225. 
да помажу стварању општенационалног, приступачног народу, савременог књижевног језика.

Овде не можемо да се задржимо на свим аспектима таквог поређења, нити да изнесемо све резултате до којих смо дошли. Због тога смо одабрали питање црквенословенске лексике, јер је однос према њој (у конкретном случају одговарајућа преводилачка решења) карактеристичан за разлике у путевима изградње бугарског и српског књижевног језика у 19. веку. У центру наше пажње биће језик Неофитовог превода и оне карактеристичне особине два превода у односу на црквенословенски текст Новог завета које се истичу при њиховом поређењу

Док је код В. Караџића проблем био како превести Свето писмо користећи у највећој мери народни начин изражавања у граматици и лексици, дакле само оно што народ говори, задатак Н. Рилског као преводиоца био је да усклади стихију народног језика са књижевном традицијом. Ово је Н. Рилски постигао у првом реду коришћењем потпуно народне новобугарске граматике, при чему су неки облици у одређеним случајевима дијалекатски маркирани; запажа се ограничен број варијаната код незваничних средстава, али се поред тога примећује свестан избор и доследно придржавање прихваћених морфолошких и синтактичких норми. Има доста чисто народних речи из разговорног језика, али основну речничку грађу сачињава неутрална општебугарска лексика, традиционални народни слој. За разлику од В. Караџића, Н. Рилски се доследно придржава књижевног облика личних имена и месних назива у тексту Новог завета, кодификованог у штампаним црквенословенским текстовима, укључујући и етнониме и називе локалне припадности. Сачувана су грчка имена новаца и мера према црквенословенском тексту, а такође и називи материја и драгог камења.

Превод Н. Рилског је усклађен са црквенословенским текстом у погледу употребе знатног броја речи с разноврсном семантиком, од којих већина потиче из старобугарских превода. Преовлађују именице и глаголи, али се у погледу творбе речи не примећује доминација одређеног типа. Ту ћемо само навести неколико примера који показују да је при превођењу ових лексема Вук доследно користио српске народне речи, док Н. Рилски чува изворне облике: волеви - мудраци, жребіи - коцке,

${ }^{6}$ Примере из Неофитовог превода наводимо поједностављеном графијом и савременим шрифтом. Вуков превод наводимо према издању: Сабрана дела Вука Каращића, X, с. 13-459. При поређењу са црквенословенским текстом користили смо издање Библије Санктпетербургъ, 1800. Паралелно смо користили и превод Новог завета из 1857, који је вероватно остварен и уз учешће П. Р. Славејкова, као и синодални превод из 1925. 
вина - кривица, радуйсл - помоз' Бог, полкъ - чета, бользни - страдань, начало - почетак, изыци - народи, съдалище - столииа, смирлва се понижује се, чада - дјеца, геенна - пакао, мытори - цариници, блуднииьь - курва, прелищавате се - варате се, человъкъ домовить - домаћин, токмо - осим, жертва - прилог, сотвориха совъть - начинише вијећу, утроба - трбух, туне - бадава, часъ - сахат, обличиго - покарај га, развращенныи - покварени, осквернава - погани, блюдо - круг, дъвица - јјевојка, сокровище - благо, плащаница - платно, мірь - свијет, от похоть - од воле, пласть - тијело, поклонииць - богомољии, въ мене пребывае - стоји у мени, роптать - вичу, вопни - војници, сотвик - капетан, погибель - пропаст, свъть - видјело, слово - ријеч, блажени са... - благо онима..., лесть - превара и др.

Утицај црквенословенског текста, међутим, испољава се најснажније код сложеница и творбених типова на -тель (код назива вршилаца радње), -ніе (код глаголских именица), -іе (код апстрактних именица). У тим случајевима Н. Рилски се доследно придржава црквенословенске лексике, док је В. Караџић елиминише путем увођења српских народних речи и коришћења других творбених структура при стварању неологизама.

Поређење с Вуковим преводом омогућило је успостављање следећих односа.

\section{1. Сложенице}

Прилаз В. Караџића сложеницама у црквенословенском тексту Новог завета одавно је проучен и оцењен према постигнутим резултатима и Вуковим схватањима о српском књижевном језику․․ Ј. Живановић наводи 85 сложеница из црквенословенског текста Новог завета којима у Вуковом преводу у већини случајева одговарају синтагме, у 25 случајева - прост израз, док је реченицу В. Караџић користио углавном за оне црквенословенске сложенице које су ушле у руски језик и које је радо прихватао славеносрпски тип књижевног језика. Само у 19 случајева је В. Караџић преводио композитом, при чему је у 11 случајева користио традиционални словенски израз у оригиналном или посрбљеном обли-

7 Упор. Ј. Живановић, Како је Вук преводио са ирквенословенскога сложене ријечи у Новом завјету?, „Богословски гласник”, књ. 16/6, Ср. Карловци, 1909, с. 445-455; Вл. Мошин, нав. дело, с. 657-662, с. 673; И. Грицкат, Вуков превод Новог завета као споменик великог филолочког настојағьа, Јужнословенски филолог, XXVI, 1-2, Београд, 1964, с. 219-245, пос. с. 241-244; О. Цвијић, О неким речима y преводу Новога завета, Јужнословенски филолог, XXVI, 1-2, Београд 1964, с. 401-412, пос. с. 401. 
ку и у 8 случајева - подесну сложеницу. Закључак је да „сложенице Вук употребљава врло нерадо” и избегава црквенословенске сложенице по грчком обрасцу јер су „против духа српскога или словенскога језика” (по мишљењу А. Белића) ${ }^{8}$.

У свом преводу Неофит Рилски је врло радо прихватио црквенословенске типове сложеница. Наводимо примере само из 4 дела Новог завета:

Дела апостолска: 38 сложеница (13 - са бого-, 25 - са благо-). У 10 случајева јављају се сложенице и у Вуковом преводу (3 сложенице имају различиту структуру).

Откривење Јована богослова: 20 сложеница у преводу Неофита, 4 - у преводу Вука (вседержитель - сведржител; благодать - благодат; благословеніе - благослов; ідолослужители - идолопоклоници). Јеванђеље по Матеју: 22 сложенице. У 7 случајева сложеницу налазимо и у Вуковом преводу (маловъриы - маловјерни; благословенб, благословАва - благослови, благосила; лицемвріе, лицември - тицемјерје, тицемјери; многоивненъ бисерв - многоијено зрно бисера; древодвлскіо сынъ - дрводјелин син; Иродъ четвертовлажникъ - четверовласник; из црквенословенског текста прихватио је Н. Рилски изычници, Вук преводи неологизмом незнабошии).

Важна је чињеница да је у 8 случајева Неофит превео сложеницом црквенословенске једноставне речи: ЖЕНИХЬ: младоженицб - женик; ЦЂЛЫ: простодушни - безазлени; НА РАСПоัТїХЬ, ИСХюДИЩА Пг ТЕИ: на крбстопьтищата - по распутииама, на раскрића; СогЬ: правосудіе - правда; ТРгСС: землетрасеніл - земла ће се трести; ПРИВРЕМЕНЕНЬ: маловремененъ - непостојан; ТЕКТОНОВЪ: древодъласкіо - дрводјелин; у перифрази: длъго богомолство лицемърно - лажно се Богу молити дуго.

Посланица Јаковљева: 25 сложеница. У 8 случајева употребио је сложеницу и Вук, у 8 случајева - само Неофит, преводећи црквенословенске једноставне речи: смртоносан, благоситамо, благослов, нелицемјерна, благодат, законодаваи, прелуубочинии, прељубочинице; ВБРЕНЬ - благочестивъ, НЕ ПРЪЛЮБЫ СОТВОРИШИ - непрелюбодъйствувай, ПРЕСТУПНИКЪ ЗАКОНА - законопреступникъ, ОТЕЦЬ - праотецъ, МИЛОСТЬ - милосердіе, СЛАСТИ - сладострастіл, ЩЕДРЬ - благоутробенг.

Поређење Јаковљеве посланице са црквенословенским текстом, савременим руским преводом и преводима из 1867. и 1925. дало је занимљив резултат: у 15 случајева исту сложеницу налазимо и у Синодал-

8 Упор. Вл. Мошин, нав. дело, с. 668. 
ном преводу из 1925 (благочестие, благочестив, законодател, замеделеи, драгоценен, злострадание, смғртоносен, благословям, благословение, лииемерие, благодат, дблготьрпение, прелюбодействува, сладостратия, прелюбодейци, прелюбодейки); од 8 сложеница Неофита 4 сложенице користи и превод из 1867 (благочестив, благочестие, прелюбодействувам, благоутробен), док је у 4 случаја преводилац прихватио црквенословенску једноставну реч (престьпник на закона отеи, милост, сласти); превод Посланице из 1867. слаже се са Неофитом у укупно 20 случајева употребе сложеница (у 18 случајева - исте сложенице, у 2 случаја прихваћена је црквенословенска структурна варијанта). На крају, у 8 случајева ипак постоје паралелно сложенице код Вука, Неофита и у преводу из 1925 (упор. благодат, смртоносан, благосиљамо, благослов, нелицемјерна, прельубочнии, прељубочинице, законодаваи). Скоро све сложенице у преводу из 1925. налазимо и у руском преводу, мада, како смо управо показали, црквенословенски текст није имао у свим овим случајевима сложеница.

\section{2. Именице са суфиксом -тель}

В. Караџић није користио суфикс -тель при стварању неологизама, неопходних за превод Новог завета. Преовлађују именице са суфиксима: -ач (13) и -ник, које налазимо у његовом речнику из 1852. године (даље Речник $)^{9}$. О. Цвијић наводи 2 именице на -тељь између оних 37 речи које нису забележене у Вуковом предговору, нити у Речнику, али су их вероватно користили високообразовани људи. Шест именица на -тель припада групи црквенословенских речи (2. група), а код посрбљених (3. група) преовлађује суфикс -ац; наведена је само једна именица на -тель (сведржитељ).

В. Караџић не укључује у друго издање Речника именице мучитељ и читатељ (не спомињу се у предговору), којима се, према А. Белићу, служила интелигенција ${ }^{10}$.

Н. Рилски је, у свом преводу користио већи број назива за вршиоце радње са суфиксом -тель. Он је проширио њихов круг не само у поређењу са црквенословенским текстом, већ и у поређењу са именицама на -тель, наведеним у речнику Н. Рилског и у црквенословенском реч-

\footnotetext{
9 Вл. Мошин, нав. дело, с. 668-669.

10 О. Цвијић, нав. дело, с. 402, 404.
} 
нику Саве Петковића ${ }^{11}$. Мада ређе, Н. Рилски употребљава и придеве на -тельнь.

У преводу Јеванђеља по Матеју Н. Рилски је користио 7 именица на -тель. Вук Караџић се слаже са црквенословенским текстом само у 2 случаја (родитеље, Јован Крститель). Н. Рилски је употребио 5 нових именица на -тель. Наводимо их у поређењу са црквенословенским текстом и Вуковим преводом: СБАИ: съАтель - сијач; ВОЖДИ: водители вођи; ЗИЖДгЩЇИ: зидатели - зидари; КЬ ПРОДАЮЩЫМЬ: при продавателите - к трговиима; КЛЕВРБТЫ СВОА: сослужителите си - своје другаре.

У Јаковљевој посланици употребљено је 9 именица на -тель од којих у 2 случаја налазимо сличну именицу и код Вука (пријатељ, учитељ). Исто тако, у осталим случајевима именице на -тель код Н. Рилског не одговарају црквенословенским речима које је морао превести: РАБЪ служитель, ТВОРЕЦЪ - творитель, ЗАКОНОПОЛОЖНИКЬ - законодатель, СХОДНИКИ - соглАдатели, ПРАВАЩИИ - управитель, ДРугГЬ - прихтель.

3. Резултати поређења глаголских именица на -ніе и апстрактних именица на -іе откривају највише додирних тачака у прилазу ове двојице преводилаца.

Између 49 црквенословенских речи наведених у предговору код В. Караџића нема ни једне именице на -нie, -ie, у а групи посрбљених речи (од свега 47) има их 20: на -је, -љье: тицемјерје, невјерје, сујевјерје; изобиъе обиле, братольблье, човјекольубље, сребролублье; на -юе (највише - 12): искушене, непоштеђене, обрезане, необрезане, откривене, отпуштене, помитоване, поучене, противльеье, сазидане, уздржане, неуздржане.

Између 84 неологизма 23 се завршавају на -ње (већина од глагола свршеног вида), што представља четвртину свих нових речи које је Вук створио за потребе превода: избавльене, извршене, обновлене, окаменьеье, оправданье, опушћене, осуђенье, очишћене, познане, покајане, помазане, помирене, понижене, посвећене, посиеньене, послушане, непослушане, потврђене, похођене, приготовљеюе, признате, примиреюе, утврђеюе. Пет од њих је укључено у Речник, али међу њима нема ниједне именице на -юе из групе посрбљених. О. Цвијић наводи још 9 именица на -юе: кађене невјероване, нештеђене, пошћене, искушане, освећене,

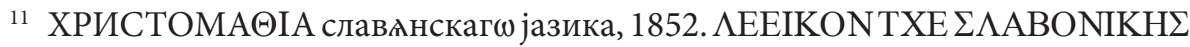

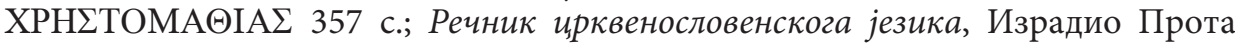
Сава Петковић, Сремски Карловци, 1935. 
прерађене, преступьене, примљене (од глагола свршеног вида; нису укључене у Речник) $)^{12}$.

Шест именица према О. Цвијић регистровано је у најранијим речницима (из 16. и 17. века) и код старих хрватских књижевника (из 16. и 17. века): кађеюе, невјероване, искушање, прерођене, преступьеюе, примљенье ${ }^{13}$

Код Н. Рилског именице на -ніе и -іе су широко заступљена творбена категорија. Тако је у Јаковљевој посланици употребљено 25 глаголских именица на -ніе (од њих 3 сложенице) и 9 на -іе (од њих 4 сложенице): постаніе, искущеніе, терпвніе, смиреніе, начинаніе, даваніе, созданіе, слушаніе, говореніе, гнъваніе, оскверненіе, помышленіе, писаніе, повельніе, намъреніе, обраштеніе, благословеніе, сомнъніе, желаніе, заколеніе, прихожденіе, злостраданіе, долготерпъніе, осужденіе, согръшеніе; благочестіе, подноженіе, арзличіе, насиліе, подобіе, милосердіе, лицемъріе, сладострастіе, усердіе. Подударности с именицама коришћеним у Вуковом преводу нема, али у 5 случајева и код Вука наилазимо на глаголске именице на -юе: кушағе, трпљеюе, створење, заклаюе, страдаюе и у једном случају на -је: подножје.

У преводу Откривења Јована богослова Н. Рилски је користио 28 именица на -ніе (од њих 4 сложенице): откровеніе, терпъніе, изступленіе, ученіе, служеніе, созданіе, почиваніе, благодареніе, благословеніе, землетрлсеніе, спасеніе, молчаніе, мученіе, водъніе, дозволеніе, блудодълніе, знаменіе, пльненіе, приноченіе, кричаніе, погубленіе, запаленіе, гореніе, рыданіе, волхованіе, воскресеніе, основаніе, исиълені. У 2 случаја В. Караџић је употребио исту глаголску именицу: спасеније, васкрсеније. У 7 случајева њима одговара именица на -юе: откривене, трпльеье, створене, мучете, постане, горень, исијетьване.

Важно је истакнути да Н. Рилски, мада ређе, уводи глаголске именице народног типа на -не (код њега се оне пишу са -нъ;, а у неким случајевима код облика на -ніе место акцента указује да се ради о именицама

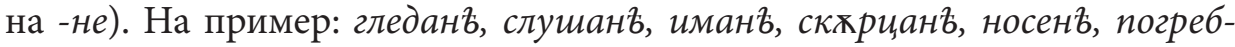
уван $b$, падан $b$, отдххнован $b$, евентуално и даваніе, слушаніе, говореніе, гнъваніе, прихожденіе. Већина глаголских именица на -ніе сачувана је и у преводу из 1925. г., али је повећан број облика народног типа на -не. У преводу из 1867. г. именице на -ніе су уобичајено средство за преводиоца и тај се превод у већини случајева подудара с преводом Н. Рилског. Очигледно је да у кругу новозаветне лексике глаголске именице на -ніе

12 О. Цвијић, нав. дело, с. 405.

13 О. Цвијић, нав. дело, с. 410. 
представљају црквенословенску групу, за разлику од именица на -тель које су обогаћене под руским утицајем. Ово потврђује и поређење с црквенословенским речником Н. Рилског уз његову црквенословенску хрестоматију. Од могућих црквенословенских речи у Јаковљевој посланици у речнику Н. Рилског нема 15. Дванаест од њих су: називи вршилаца радње на -тель (7 од свега 9 у тексту) и глаголске именице на -ніе (5 од свега 25; вероватно су схватане као глаголске именице на -не). Из Откривења Јована богослова у речнику Н. Рилског нема 41 речи, али 17 од њих налазимо у речнику Саве Петковића. Од 6 именица на -тель нема 2, а од 28 именица на -ніе - 3.

Резултати поређења два превода своде се на следеће закључке:

1. Превод Н. Рилског остварен је, као и Вуков, на народном језику. Књишки елементи, коришћени с обзиром на црквенословенски образац, у већини случајева се подударају с преводом из 1867. г. (по свој прилици рад П. Р. Славејкова, који је паралелно с црквенословенским текстом издало у Њујорку Америчко библијско друштво). Као заједничко наслеђе, ове групе су заступљене и у савременом синодалном преводу из 1925. г.

2. Састав црквенословенске лексике у преводу Н. Рилског одражава објективни ток процеса изградње лексичке књижевне норме у бугарској препородној књижевности ${ }^{14}$. Нарочито интересантан у том погледу је проблем сложеница. У ствари, тенденција прихватања готових црквенословенских и руских композита и стварање нових по истим моделима у бугарској књижевности из доба препорода на веома специфичан начин се преплеће с творбом неологизама по чисто народним моделима за сложенице (на пример код пуристе Ивана Богорова). Ове некњижевне по типу сложенице нису биле успешне и нису имале могућности за интеграцију у већ постојећи фонд књижевних речи. Што се тиче самог начина грађења речи - тзв. композиције, мора се имати у виду да последња проучавања творбе речи у бугарским дијалектима дају неупоредиво више грађе него што бисмо очекивали код старих словенских композита ${ }^{15}$. У

14 Сам однос према стварању књижевне лексике налазимо у речнику $\mathrm{H}$. Рилског којим се завршава Болгарска граматика (с. 204-211); РҒчи Турски и нъколко Гречески... „истолкуваны по возможности съ равнознаменателны Славенски или Русійски". За замену ове 221 речи Н. Рилски уводи међу осталим 20 сложеница, 25 именица на -нie, 11 - на -ie, 13 именица на -тель. О типовима књижевних суфикса упор. Хр. Първев, Проблеми..., с. 9-10.

15 Упор. М. Троева, Сложни имена за тица със суфикс-еи, в българските говори, Славистичен сборник, София, 1978, с. 197-203; Ю. Балтова, Изграждане на книжовна лексика в българския език през Вьражданета. (Сложни същестеител- 
том смислу за позитивни однос препородних књижевника према сложеницама несумњиво је одиграо улогу не само пијетет према старобугарском језику и црквенословенској књижевности, него и чињеница да су образовани људи познавали грчки језик (нарочито до четрдесетих година, када почиње руски културни утицај), а по свој прилици и потенцијалне могућности композирања у бугарским дијалектима ${ }^{16}$.

3. Превод на народни језик једног текста као што је Нови завет код којег постоји изванредно дуга текстуална и преводна традиција, увек је постављао специфичне задатке у вези с његовим језичким обликовањем, наметнуте сакралним карактером текста и постулатима средњовековног преводилачког приступа.

Чињеница да је В. Караџић имао за циљ да оствари преводни текст само на бази језичких средстава простог сељачког говора истиче у први план тежњу за тачним преношењем смисла новозаветног текста и за максималним одвајањем од изражајног облика његове црквенословенске верзије, неразумљиве за народ ${ }^{17}$. На тај начин Вук је извео један текст с престижном традицијом из граница средњовековног канона и максимално га ослободио реалија епохе у којој је био створен и историјске дистанце према описаним збивањима.

М. Поповић веома тачно одређује значај архаичних речи које је Вук, пошто је био приморан, свесно користио у свом преводу: „оне су давале духовне богатом библијском тексту патину свечане древности”18. Тачно је такође да је В. Караџић мењао своја схватања о књижевном језику; управо употреба 96 црквенословенских речи (од њих 47 посрбљених) и 84 неологизма у духу народног језика сведочи о томе да је он прихватио

нu - nomina concreta), Известия на Института за български език, XXV, 1983, с. 9-11, c. 27.

16 О сложеницама у бугарској књижевности из доба препорода види Хр. Първев, Езикът на Необит Бозвели, „Български език”, XV, 6, 1965, с. 473-487; Ю. Балтова, Някои видове compossita в българския книжовен език през Въраждането, Български език, XXVI, 5, 1976, с. 372-379; Ю. Балтова, За словообразователната синонимия и вариантност при композитумите в българския кн ижовен език през периода на Възраждането, Български език, XXIX, 3, 1979, с. 205-208; Ю. Балтова, Изграждане на книжовна лексика в българския език през Вьзраждането, ИИБЕ, ХХV, 1983, с. 8-31.

17 Упор. истраживања о Вуковом језику и стилу у Јужнословенском филологу, XXVI 1-2, Београд, 1963-1964. Посвећено стогодишњици смрти Вука Ст. Караџића; Вл. Мошин, нав. дело.

18 Вл. Мошин, нав. дело, с. 703. 
став да „речничко благо народног језик није довољно за потребе књижевног језика"19.

У његовом преводу има особина које одступају од језика народног песништва. Па ипак, када је реч о стварању књижевног језика, један библијски (у ширем смислу речи) текст мора да буде и стилистички маркиран. А. Белић с правом сматра да В. Караџићу „није било важно стварање библијског језика као таквог, већ јасна и разумљива текста"20.

Резултат је веома сажето оценила И. Грицкат: „Тачно је да је Вук у највећем делу овог превода постигао своје савршенство, али је тачно и то да му садржај и стил Библије углавном нису били блиски... Тако да се у овом делу нарочито на местима спиритуалн их, не ретко и тамних апстракција, његов стил у суштини показао неспреман"21.

Доследност с којом Н. Рилски прихвата црквенословенску лексику не мора се објашњавати само концепцијом славенобугарске школе. Још од новобугарских дамаскина, а касније и у „простом” језику књижевника 18. века, традиционални средњовековни књижевни језик присутан је у писменом изразу преко лексике. Црквенословенска штампана књижевност помаже укључивању овог књижевног слоја у новобугарски књижевни језик ${ }^{22}$. Из ових разлога, везаних за особине језичке ситуације на бугарском подручју током 18. века, Н. Рилски, уз увођење чисто народне граматике, успео је да пренесе у свој превод готове језичке елементе који га дистанцирају од народног језика и тако сачува обавезну за библијски текст „патину свечане древности”.

У преводу Н. Рилског наилазимо и на неуспешне и тешко разумљиве изразе; бугарски књижевни речник није прихватио све црквенословенске речи. Али у свом прилазу, у усвајању традиционалне (црквенословенске) лексике, Н. Рилски као преводилац није прекорачио меру на којој се базира нормативни систем националног бугарског књижевног језика.

19 П. Ивић, Развој Вукових погледа на српски кюижевни језик, Зборник за филологију и лингвистику, XXI, 1, Нови Сад, 1978, с. 133-141, с. 140.

20 Упор. Вл. Мошин, нав. дело, с. 666.

${ }_{21}$ И. Грицкат, нав. дело, с. 244.

22 Види о томе А. Мишчева, Ролята на традицията при възникването на новобългарския книжевни език, Годишник на Софийския университет, ФСФ, Езикознание, Т. 77, I за 1983, София, 1986, с. 75-123. 


\section{ПРИЛОГ}

Из превода Неофита Рилског, Лука 10. 30-35. Упор. са Вуковим бугарским текстом Новог завета: Сабрана дела Вука Караџића, X, Нови Завјет, Београд, 1974, с. 1186-1189 (Огледи Бугарског превода Новог завјета, 1822)

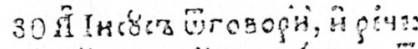

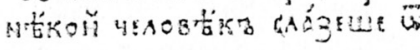

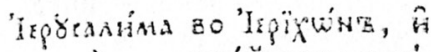

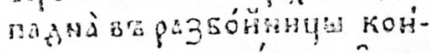
To katoro romékoXa, Giannompix my pátes whóxs sh,

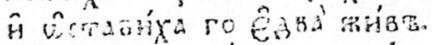

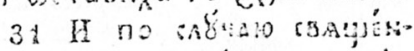

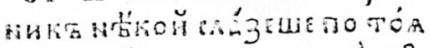

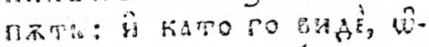

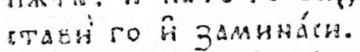

32 Подо́⿴N⿴囗十 , H H

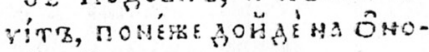

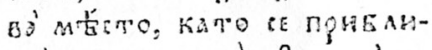
:

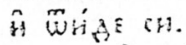

33 Ho ÊAнís Gamapanígr,

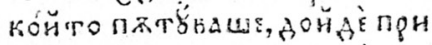

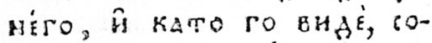

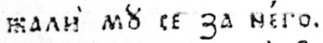

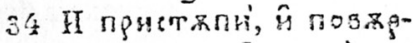

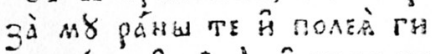

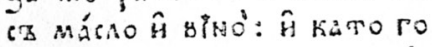

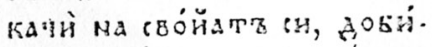

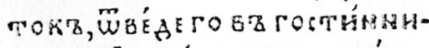

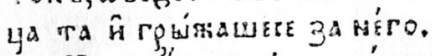

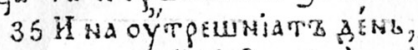
КАन० СИ ПОН̆ вр́́в

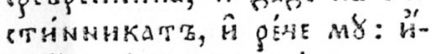
mă̈ rqússa za Torósa yeno-

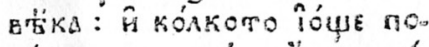
Xа́pчthus 3 a Néro, äzz Korá-

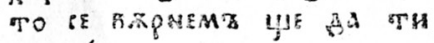
उanAáTHMr.

* Рад је претходно објављен у зборнику Научни састанак слависта у Вукове дане, 17/2, 59-69. 